\title{
RELASI GENDER DAN KEBERLANJUTAN KAMPUNG RAMAH LINGKUNGAN PANDAWA 5 CIBINONG, KABUPATEN BOGOR
}

\section{Gender Relation and Sustainability of Ecovillage Pandawa 5 Cibinong, Bogor District}

\author{
Charina Ardinal*, Siti Amanah \\ Departemen Sains Komunikasi dan Pengembangan Masyarakat, Fakultas Ekologi Manusia, Institut \\ Pertanian Bogor, Dramaga Bogor 16680, Indonesia \\ *)E-mail: Ardinalcharina@gmail.com;
}

\begin{abstract}
Ecovillage Pandawa 5 is one of the community initiative undertaken in Cibinong - Bogor. This initiative has been supported by the households of Pabuaran Mekar Village. Gender equity and equality in the household affect the ecovillage performance. The research aims to analyze the gender relation in a household, then analyze the influence of household characteristic toward gender relation and at last, to analyze the correlation of gender relation with the sustainability of Eco Friendly Village Pandawa 5 in Pabuaran Mekar Village, Bogor Regency, West Java. The research method used is quantitave methodlogy support by qualitative assestment. The results show that the gender relation in Ecovillage Pandawa 5 household is equal. The education level of husband and wife in the households influence the gender relation, and there is positive correlation between gender relation and the sustainability of social-culture Keywords: MDH's capacity, MDH's response, social forestry
\end{abstract}

Keywords: Eco Friendly Village, KRL Pandawa 5, Gender Relations, Sustainability

\begin{abstract}
ABSTRAK
Kampung Ramah Lingkungan (KRL) merupakan suatu gerakan pembangunan berkelanjutan berbasis gerakan masyarakat. Relasi gender yang berimbang dalam rumah tangga dapat mendukung keterlibatan anggota rumah tangga dalam pembangunan. Penelitian ini bertujuan menganalisis relasi gender dalam rumah tangga anggota KRL Pandawa 5 dan hubungan antara relasi gender dalam rumah tangga dengan keberlanjutan KRL Pandawa 5 di Kelurahan Pabuaran Mekar, Kabupaten Bogor, Jawa Barat. Metode survei digunakan dalam penelitian. Tiga puluh dari 42 rumah tangga peserta KRL terpilih sebagai responden penelitian. Hasil analisis deskriptif menunjukkan bahwa relasi gender dalam rumah tangga KRL Pandawa 5 berada pada kategori cukup setara. Analisis regresi menunjukkan bahwa tingkat pendidikan suami dan istri berpengaruh terhadap kesetaraan gender dalam rumah tangga. Analisis korelasi Spearman memperlihatkan bahwa terdapat korelasi nyata antara relasi gender dan keberlanjutan sosial budaya dari KRL.
\end{abstract}

Kata Kunci: Kampung Ramah Lingkungan (KRL), KRL Pandawa 5, Relasi Gender, Pembangunan Berkelanjutan 


\section{PENDAHULUAN}

Pembangunan pada dimensi ekonomi dibatasi oleh ketersediaan alam. Kemajuan yang ditawarkan adalah kemajuan yang merusak atau tidak lestari. Hal ini menyebabkan kebutuhan atas konsep pembangunan yang memperhatikan dimensi lainnya, seperti dimensi ekologis dan sosial. Konferensi Tingkat Tinggi (KTT) Bumi di Rio de Jenairo pada tahun 1992, mempertegas bahwa semakin banyak negara di dunia yang mulai prihatin melihat kerusakan bumi yang disebabkan oleh pertumbuhan ekonomi yang tidak hijau hingga tercetuslah konsep pembangunan yang tetap bertanggung jawab pada kelestarian alam. The Brundtland Report yang dirilis oleh The World Comission on Enviroment and Development pada tahun 1987 menjadi awal pengenalan istilah sustainable development atau pembangunan berkelanjutan. Brundtland Commission dalam Asdak (2012) mendefinisikan pembangunan berkelanjutan sebagai pembangunan yang memenuhi kebutuhan kita saat ini tanpa mengurangi kemampuan generasi selanjutnya untuk memenuhi kebutuhan mereka. Mugniesyah (2007) mengatakan salah satu karakteristik dari pembangunan berkelanjutan adalah penekanan pada keterkaitan antara dimensi ekologis dan sosial.

Berkenaan dengan pembangunan nasional, Pemerintah Indonesia sudah terlebih dahulu menerbitkan Instruksi Presiden (INPRES) No 9 Tahun 2000.

Inpres ini berisikan tentang pengarusutamaan gender dalam pembangunan nasional. Instruksi ini menjadi bukti komitmen pemerintah untuk terlibat bukan saja dalam upaya mencapai tujuan pembangunan berkelanjutan saja, namun juga pembangunan yang berperspektif gender. Gender memiliki arti yang berbeda dengan sex atau jenis kelamin. Merujuk pada UNESCO (2003), istilah gender mengacu pada peran serta tanggung jawab perempuan dan laki-laki yang dikonstruksi oleh lingkungan sekitar. Konstruksi lingkungan terhadap peran dan tanggung jawab ini menyebabkan peran dan tanggung jawab tersebut dapat berubah sewaktu-waktu karena adanya diferensiasi pada sistem sosial. Berbeda halnya dengan jenis kelamin yang merupakan sebuah perbedaan biologis yang nyata dan pasti tentang perempuan dan laki-laki.

Negara Indonesia cukup banyak terlibat dalam ratifikasi kesepakatan internasional mengenai integrasi gender dalam pembangunan. Meskipun kesepakatan tersebut sudah diturunkan menjadi Instruksi Presiden sehingga pengarusutamaan gender memiliki kekuatan hukum, namun dalam pelaksanaanya hingga kini masih saja ditemui isu ketimpangan antara perempuan dan laki-laki. Ketimpangan tersebut biasanya terjadi pada praktik-praktik dilapang seperti contoh keterwakilan perempuan dalam parlemen yang masih minim dan diskriminasi gender pada proses rekrutmen pekerjaan dan ruang publik lainnya.

Rahma (2019), mengatakan penindasan yang dialami oleh alam memiliki kesamaan dengan penindasan yang diterima perempuan. Keduanya berawal dari pratik dominasi pada budaya patriarki yang tidak adil dalam pembagian peran antara perempuan dan laki-laki. Dominasi, marginalisasi, dan subordinasi yang tidak hanya terjadi pada ruang publik tetapi juga pada ranah privat seperti dalam rumah tangga. Puspitawati (2017) menjelaskan bahwa pembagian peran dalam rumah tangga yang adil akan berpengaruh pada aktualisasi diri indvidu di rumah tangga dalam kehidupan bermasyarakat.

Salah satu upaya mencapai pembagunan berkelanjutan, Pemerintah Indonesia menginisiasi gerakan yang menunjang. Pada tingkat kabupaten, Pemerintah Kabupaten Bogor menginisiasi gerakan Kampung Ramah Lingkungan (KRL). KRL di Kabupaten Bogor yang sudah mendapat banyak penghargaan adalah KRL Pandawa 5, Kelurahan Pabuaran Mekar. Penghargaan yang diperoleh salah satunya adalah penghargaan kategori lanjutan pada Ecovillage Award tahun 2019. Keberhasilan ini pastinya didukung oleh pemahaman dan kerjasama yang baik para anggota KRL yang merupakan gabungan dari rumah tangga di RW 5 Kelurahan Pabuaran Mekar. Oleh sebab itu, menurut penulis menjadi menarik untuk menganalisis bagaimana relasi gender pada rumah tangga anggota KRL Pandawa 5 dan hubungannya dengan keberlanjutan KRL Pandawa 5. 
Tujuan penulisan "Relasi Gender dan Keberlanjutan Kampung Ramah Lingkungan Pandawa 5 Cibinong, Kabupaten Bogor" adalah: (1) Menganalisis relasi gender pada rumah tangga Kampung Ramah Lingkungan (KRL) Pandawa 5; (2) Menganalisis pengaruh karakteristik rumah tangga terhadap relasi gender pada rumah tangga anggota Kampung Ramah Lingkungan (KRL) Pandawa 5; dan (3) Menganalisis hubungan antara relasi gender dalam rumah tangga dan keberlajutan Kampung Ramah Lingkungan (KRL) Pandawa 5.

\section{PENDEKATAN TEORITIS}

\section{Relasi Gender}

Konsep Gender menjelaskan mengenai relasi peran antara perempuan dan laki-laki. Konsep gender bukan berbicara kesetaraan antara laki-laki dan perempuan yang harus sama (equal in everything) namun tentang pembagian peran yang berkeadilan. Puspitawati (2012), menjelaskan bahwa gender diartikan sebagai perbedaan fungsi, peran, status dan tanggungjawab pada laki-laki dan perempuan yang merupakan hasil konstruksi sosial yang dengan kata lain merupakan hasil kesepakatan antara manusia yang tidak bersifat kodrati. Merujuk pada UNESCO (2003), istilah gender mengacu pada peran serta tanggung jawab perempuan dan laki-laki yang dikonstruksi oleh lingkungan sekitar. Konstruksi lingkungan terhadap peran dan tanggung jawab ini menyebabkan peran dan tanggung jawab tersebut dapat berubah sewaktu-waktu karena adanya diferensiasi pada sistem sosial. Berbeda halnya dengan jenis kelamin yang merupakan sebuah perbedaan biologis yang nyata dan pasti tentang perempuan dan laki-laki. Oleh sebab itu, pembagian peran, status, fungsi dan tanggung jawab itu berbeda setiap tempat. Nilai dan norma banyak mempengaruhi relasi gender yang ada setiap tempat. Gender adalah aturan sosial yang berkaitan dengan jenis kelamin manusia.

Relasi gender adalah hubungan antara laki-laki dan perempuan perihal pembagia peran yang dijalankan dalam rumah tangga (Puspitawati 2017). Membahas mengenai hal-hal yang berkaitan dengan pembagian peran dan hubungan antara perempuan dan laki-laki yang mengatur bagaimana pembagian peran laki-laki dan perempuan dalam kehidupan sehari-hari. Pembagian peran dalam rumah tangga yang berkeadilan adalah awal dari efektifnya rumah tangga. Adanya pembagian peran ini bisa menjadi kunci harmonisnya sebuah rumah tangga. Moser (1993) menjelaskan adanya 3 (tiga) kategori peranan yaitu: 1) peranan produktif, yaitu peranan yang dikerjakan perempuan dan laki-laki untuk memperoleh bayaran tunai, termasuk produksi pasar dengan suatu nilai tukar dan produksi rumah tangga/subsisten dengan nilai guna. Contohnya kegiatan bekerja di sektor formal maupun informal; 2) peranan reproduktif, yakni peranan yang berhubungan dengan tanggung jawab pengasuhan anak dan tugas-tugas domestik untuk menjamin pemeliharaan dan reproduksi tenaga kerja yang menyangkut kelangsungan tenaga. Contoh: melahirkan, memelihara dan mengasuh anak, mengambil air, memasak, mencuci, membersihkan rumah, memperbaiki baju dan lain-lain; 3) peranan pengelolaan masyarakat dan politik, terdiri atas 2 (dua) kategori, yaitu: peranan pengelolaan masyarakat (kegiatan sosial), mencakup semua aktivitas dalam komunitas sebagai kepanjangan peran reproduktif, bersifat sukarela (tanpa upah) dan peranan pengelolaan politik, yakni peranan dalam pengorganisasian komunitas pada tingkat formal secara politik, biasanya dibayar (langsung ataupun tidak langsung), dan meningkatkan kekuasaan atau status. Peranan gender menurut Prasodjo et al. (2003) adalah peranan yang dilakukan perempuan dan laki-laki sesuai status, lingkungan, budaya dan struktur masyarakatnya mencakup: 1) peranan produktif (peranan yang dikerjakan perempuan dan laki-laki untuk memperoleh bayaran atau upah secara tunai atau sejenisnya, termasuk produksi pasar dengan suatu nilai tukar, dan produksi rumah tangga atau subsisten dengan nilai guna, tetapi juga suatu nilai tukar potensial, misalnya bekerja di sektor formal dan informal; 2) peranan reproduktif yakni peranan yang berhubungan dengan tanggung jawab pengasuhan anak dan tugas-tugas domestik yang dibutuhkan untuk menjamin pemeliharan dan reproduksi tenaga kerja yang menyangkut kelangsungan keluarga. Contoh: melahirkan, memelihara dan mengasuh anak, mengambil air, memasak, mencuci, membersihkan rumah, memperbaiki baju, dan sebagainya. 
Pembagian peran gender di Indonesia masih banyak dipengaruhi oleh nilai dan norma yang berlaku di daerah masing-masing. Setiap daerah tersebut banyak membatasi peran perempuan pada beberapa aspek. Hal ini biasanya disebabkan oleh perbedaan faktor kemampuan fisik antara perempuan dan lakilaki.

Kebudayaan yang berlaku di masyarakat masih beranggapan bahwa untuk kerja-kerja produktif yang banyak membutuhkan tenaga adalah ranahya laki-laki sehingga banyak pekerjaan utama pada berbagai mata pencaharian ditempati oleh laki-laki. Peran reproduktif yang selalu dikaitkan dengan pekerjaan domestik, tidak membutuhkan kemampuan fisik yang begitu kuat, menjadi ranahnya perempuan. Hal ini seputar memasak, mencuci, dan menjaga rumah.

Pembagian peran gender yang masi timpang ini pada beberapa artikel mengatakan dianggap biasa oleh wanita. Ketimpangan yang terjadi begitu lama dan sebenarnya berpangkat pada satu sumber yang sama yaitu pelabelan. Perempuan yang sering mendapat label sebagai seorang yang teliti, lembut dan rapih maka dapat dipastikan akan dikaitkan dengan peran reproduktif atau domestik. Perempuan yang aktif dalam ranah privat dan sosial politik akan terlihat aneh dan berbeda karena tidak sesuai dengan label yang diberi masyarakat sekitar. Laki-laki pun tak lepas dari pelabelan ini. Laki-laki yang dikenal maskulin, tangguh dan kuat akan mendapat perhatian berbeda ketika memilih peran/bidang kerja yang erat kaitannya dengan perempuan seperti menjadi koki atau yang lainnya.

Marginalisasi atau peminggiran merupakan akibat dari ketidakadilan gender. Perempuan sering kali mengalami hal semacam ini. Kasus yang sering terjadi adalah perempuan dengan posisi pekerjaan yang sama kerap kali mendapat upah kerja yang lebih rendah dari laki-laki. Selain itu hak-hak perempuan juga sering kali tidak dipenuhi dengan baik. Subordinasi adalah keadaan ketika terdapat pandangan bahwa salah satu jenis kelamin lebih utama dari yang lainnya. Subordinasi banyak terjadi pada lingkungan rumah tangga di Bali. Pengambilan keputusan hanya bisa diambil oleh laki-laki yang dianggap stratanya setingkat lebih tinggi dari perempuan. Budaya patriarki sering menjadi landasan atau pembenaran dalam kasus ini.

Kekerasan terhadap perempuan dalam rumah tangga masih menjadi kasus yang tidak pernah tuntas di Indonesia. Komisi Nasional Anti kekerasan terhadap perempuan (Komnas Perempuan) mencatat kekerasan terhadap perempuan semakin kompleks dan beragam, dengan intensitas yang meningkat, terjadi di lintas ruang, baik di ranah domestik, publik dan negara. Komnas Perempuan (2019) menjelaskan bahwa kekerasan terhadap perempuan terus menerus setiap keturunannya membuat persepsi wanita terhadap perannya pun seolah membenarkan bahwa perempuan tidak memiliki kesempatan untuk terlibat pada ranah produktif (Gelgel 2016). Pengambilan keputusan pada ranah produktif menjadi kuasa lelaki sebagai kepala rumah tangga. Pada rumah tangga perkotaan ketimpangan ini memang sudah banyak memudar. Hal ini dapat dilihat dari posisi-posisi stategis dalam sebuah perusahaan yang sudah mulai banyak diisi oleh perempuan, namun dengan begitu tidak membuat perempuan lepas dari tanggung jawabnya diranah domestik yang sudang sangat lekat dengan perempuan.

\section{Kesetaraan dan Keadilan Gender}

Gelgel (2016) pada penelitiannya tentang Kesetaraan dan Keadilan Gender (KKG) dalam pandangan perempuan Bali mengatakan bahwa ketidakadilan secara jelas terjadi dalam adat Bali yang bersifat patriarki. Masyarakat Bali memposisikan kedudukan kaum laki-laki di atas kaum perempuan. Keadilan dan kesetaraan gender menjadi gerbang awal dari isu gender yang terjadi pada perempuan maupun lakilaki. Menurut Rokhimah (2014), terdapat beberapa isu yang berkaitan dengan ketidaksetaraan dan ketidakadilan gender antara lain; Beban kerja ganda merupakan isu gender yang lekat dengan pembagian peran yang tidak berkeadilan dalam rumah tangga. Beban kerja ganda adalah keadaan dimana beban pekerjaan salah satu jenis kelamin lebih banyak dibandingkan jenis kelamin lainnya. Tetap dibebankan dengan peran reproduktif walau hal ini sering terjadi pada rumah tangga di pedesaan yang mayoritas mata pencahariannya petani, nelayan, dan buruh. 
Stereotipe, atau sering juga disebut pelabelan. Ketidakadilan gender sebenarnya berpangkat pada satu sumber yang sama yaitu pelabelan. Perempuan yang sering mendapat label sebagai seorang yang teliti, lembut dan rapih maka dapat dipastikan akan dikaitkan dengan peran reproduktif atau domestik. Perempuan yang aktif dalam ranah privat dan sosial politik akan terlihat aneh dan berbeda karena tidak sesuai dengan label yang diberi masyarakat sekitar. Laki-laki pun tak lepas dari pelabelan ini. Laki-laki yang dikenal maskulin, tangguh dan kuat akan mendapat perhatian berbeda ketika memilih peran/bidang kerja yang erat kaitannya dengan perempuan seperti menjadi koki atau yang lainnya.

Marginalisasi atau peminggiran merupakan akibat dari ketidakadilan gender. Perempuan sering kali mengalami hal semacam ini. Kasus yang sering terjadi adalah perempuan dengan posisi pekerjaan yang sama kerap kali mendapat upah kerja yang lebih rendah dari laki-laki. Selain itu hak-hak perempuan juga sering kali tidak dipenuhi dengan baik. Subordinasi adalah keadaan ketika terdapat pandangan bahwa salah satu jenis kelamin lebih utama dari yang lainnya. Subordinasi banyak terjadi pada lingkungan rumah tangga di Bali. Pengambilan keputusan hanya bisa diambil oleh laki-laki yang dianggap stratanya setingkat lebih tinggi dari perempuan. Budaya patriarki sering menjadi landasan atau pembenaran dalam kasus ini.

Kekerasan terhadap perempuan dalam rumah tangga masih menjadi kasus yang tidak pernah tuntas di Indonesia. Komisi Nasional Anti kekerasan terhadap perempuan (Komnas Perempuan) mencatat kekerasan terhadap perempuan semakin kompleks dan beragam, dengan intensitas yang meningkat, terjadi di lintas ruang, baik di ranah domestik, publik dan negara. Komnas Perempuan (2019) menjelaskan bahwa kekerasan terhadap perempuan mengalami kenaikan di tahun 2018 yaitu sebanyak 406.178 kasus dari 348.446 kasus di tahun 2017.

\section{Analisis Gender}

Penggunaan alat analisis gender disesuaikan dengan tujuan penelitian, unit analisis penelitian dan sumberdaya yang ada. Berbagai jenis gender-analysis frameworks memiliki fokusnya masing-masing, walau tak menutup kemungkinan untuk melakukan kombinasi dari beberapa alat analisis gender. Pada penelitian ini, alat analisis gender yang digunakan adalan Analisis Harvard. Merujuk pada A Guide to Gender-Analysis Frameworks, Analisis Harvard adalah kerangka analisis gender yang digunakan untuk melihat pembagian peran dalam rumah tangga dan menganalisis pembagian akses dan kontrol terhadap sumberdaya dan manfaat antara laki-laki dan perempuan dalam rumah tangga. Kerangka analisis ini berbentuk matriks yang membagi peran laki-laki dan perempuan kedalam tiga kategori yaitu peran reproduktif, peran produktif dan peran sosial. Selain, membuat matriks profil kegiatan gender, terdapat pula matriks pembagian akses dan kontrol terhadap sumberdaya diantara perempuan dan laki-laki. Dan langkah terakhir adalah dengan menganalisis faktor-faktor yang mempengaruhi relasi gender dalam rumah tangga.

\section{Pembangunan Berkelanjutan}

The Brundtland Report yang dirilis oleh The World Comission on Enviroment and Development pada tahun 1987 menjadi awal pengenalan istilah sustainable development atau pembangunan berkelanjutan. Keraf (2002), menjelaskan adanya pergeseran etika lingkungan dari yang berpusat pada manusia (antroposentrime) beralih menjadi berpusat pada alam (ekosentrisme). Daya dukung lingkungan yang sebelumnya memprioritaskan kebutuhan manusia semata terutama dimensi ekonomi dirasa hanya menimbulkan kerusakan di mana-mana. Produktivitas menjadi ujung tombak pembangunan saat itu tanpa mempertimbangkan dimensi ekologis dan sosial. Pembangunan berkelanjutan hadir seakan menjadi jawaban dari kerusakan yang ditimbulkan. Konferensi Tingkat Tinggi (KTT) Bumi di Rio de Jenairo pada tahun 1992, mempertegas bahwa semakin banyak negara di dunia yang mulai prihatin melihat kerusakan bumi yang disebabkan oleh pertumbuhan ekonomi yang tidak hijau hingga tercetuslah konsep pembangunan yang tetap bertanggung jawab pada kelestarian alam. Menurut Asdak (2012), pembangunan berkelanjutan dapat didefinisikan sebagai pembangunan yang memenuhi kebutuhan kita saat ini tanpa mengurangi kemampuan generasi selanjutnya untuk memenuhi kebutuhan mereka. Mugniesyah (2007), mengatakan salah satu karakteristik dari 
pembangunan berkelanjutan selalu dihubungkan dengan dimensi ekologis dan sosial. Fauzi dan Oxtavianus (2014), mengatakan pembangunan berkelanjutan pada hakikatnya memiliki prinsip keseimbangan dimensi ekologis, ekonomi, dan sosial.

\section{Indeks pembangunan berkelanjutan}

Sebagai sebuah cita-cita maka pembangunan berkelanjutan haruslah dapat diukur agar mudah dalam membuat perencanaannya, mengupayakan pencapaiannya hingga mengukur evaluasinya. Oxtavianus (2014), melalui penelitiannya menjelaskan bahwa untuk mengukur pembangunan dapat menggunakan beberapa indikator yang disalin dari beberapa sumber. Pertama.

Hak T, Moldan B dan Dahl Arthur (2007) menyebutkan setidakya pada aspek lingkungan-ekonomi diukur dengan produktivitas sumberdaya (misal: GDP) dan intensitas transportasi. Pada aspek sosialekonomi menggunakan produktivitas tenaga kerja, distribusi dan pendapatan perkapita. Pada aspek ekonomi kelembagaan menggunakan tingkat korupsi dan share pajak negara. Pada aspek sosialkelembagaan menggunakan jaminan kesehatan dan jaminan sosial dan terakhir pada aspek lingkungankelembagaan meggunakan tingkat kebebasan informasi.

Kedua, Jesinghaus J (2007) menyebutkan pada aspek dimensi sosial dappat diukur dengan populasi penduduk di bawah garis kemiskinan, koefisien gini, pengangguran, upah pekerja pabrik (laki-laki dan perempuan), balita kurang gizi, tingkat kematian balita, harapan hidup dan kelahiran, fasilitas pembuangan limbah, akses air bersih, akses fasilitas kesehatan, imunisasi anak, akses terhadap kontrasepsi, akses terhadap pendidikan. Pada dimensi lingkungan: ekosistem yang dilindungi, jumlah mamalia dan burung, emisi $\mathrm{CO}^{2}$, emisi lainnya, CFCS, polusi perkotaan, lahan pertanian yang subur dan permanen, penggunaan pupuk, penggunaan pestisida, areal hutan, intensitas penebangan kayu hutan, areal lahan kering, jumlah fosfor dalam air di perkotaan, populasi di pesisir, persentase produksi ikan, penggunaan air yang dapat diperbarui, bod air, kandungan bakteri coli dalam air perkotaan dan area yang diproteksi. Pada dimensi ekonomi: pendapatan per kapita, investasi, neraca perdagangan barang dan jasa, hutang luar negeri, bantuan pembangunan, input langsung, penggunaan pupuk, penggunaan energi komersial, sumberdaya energi yang dapat diperbarui, efisiensi energi, tempat pembuangan limbah yang layak, tempat pembuangan limbah berbahaya, pembuangan limbah nuklir, pengolahan limbah. Pada dimensi kelembagaan menggunakan implementasi strategi pembangunan berkelanjutan, keanggotaan organisasi lingkungan, penggunaan internet, jaringan telepon, pengeluaran untuk penelitian dan pengembangan, biaya yang dikeluarkan penduduk untuk bencana.

Ketiga, Bappenas (2007) menjelaskan parameter bidang lingkungan adalah kadar $\mathrm{CO}^{2}, \mathrm{COD}$ dan land cover. Parameter kunci bidang ekonomi adalah PDRB per kapita, persentase investasi terhadap PDRB dan distribusi pendapatan. Parameter kunci bidang sosial adalah serta angka kematian balita, jumlah anak yang mencapai wajib belajar 9 tahun dan pengangguran. Terakhir, pada penelitian Ramdan, Kusumana dan Walla (2016), yang mengukur keberlanjutan pengembangan ecovillage, digunakan indikator kesesuaian lahan, pemanfaatan laham miring, perlindungan mata air, pengolahan sampah dan limbah padat untuk aspek ekologi. Perubahan lingkungan sekitar terhadap ekonomi masyarakat, dukungan masyarakat untuk menciptakan usaha untuk aspek ekonomi. Frekuensi penyuluhan lingkungan, konflik lingkungan, komitme bersama dalam perbaikan lingkungan, kelembagaan yang mendukung lingkungan, partisipasi masyarakat pada program lingkungan untuk aspek lingkungan.

\section{Kampung Ramah Lingkungan}

Peraturan Menteri Negara Lingkungan Hidup Republik Indonesia Nomor 19 Tahun 2012 tentang Program Iklim menjadi awal dari munculnya gerakan "Eco Village" di Indonesia. Sementara itu, melalui Peraturan Daerah Kabupaten Bogor Nomor 6 Tahun 2015 tentang Desa, muncul inisiasi kegiatan kampung ramah lingkungan pada tingkat daerah. Perda ini adalah salah satu landasan hukum adanya kegiatan Kampung Ramah Lingkungan (KRL) di Kabupaten Bogor. Kampung Ramah Lingkungan adalah Suatu lokasi yang masyarakatnya melakukan upaya atau tindakan nyata dalam perlindungan dan pengelolaan lingkungan hidup secara terstrukur dan berkesinambungan. Sejalan dengan cita-cita pembangunan berkelanjutan kegiatan ini bertujuan untuk mendorong Pemerintah 
Daerah, Dunia Usaha dan masyarakat setempat untuk memahami permasalahan lingkungan dan dampaknya, serta melakukan tindakan nyata secara proaktif yang berkontribusi kepada upaya perlindungan dan pengelolaan lingkungan hidup.

Kegiatan KRL cukup padat, mencakup pengendalian kekeringan, banjir dan longsor melalui kegiatan penghijauan, pengelolaan sampah dan pembuatan lubang biopori, penyediaan bank sampah dan kreasi sampah daur ulang, penyediaan tanaman vertikultur dengan memanfaatkan lahan pekarangan rumah demi terciptanya Kawasan Rumah Pangan Lestari (KRPL). Selain itu Dinas Lingkungan Hidup Kabupaten Bogor juga mendelegasikan fasilitator ke setiap lokasi untuk melaksanakan pendampingan selama 6 bulan. Walaupun fakta di lapangan menyatakan banyaknya kegiatan KRL ini sudah sangat mandiri dan kehadiran fasilitator jarang dirasakan masyarakat langsung kecuali pejabat desa.

KRL memliki kegiatan yang beragam, seperti pengelolaan sampah. Dimulai dari edukasi mengenai pengelolaan sampah secara benar mulai dari pentingnya pemilahan sampah dari rumah, pembentukan bank sampah, komposting hingga bagaimana membuat sampah menjadi barang yang mempunyai nilai ekonomi. Lalu, konservasi atau penghijauan program ini mengupayakan masyarakat untuk memaksimalkan pemanfaatan lahan baik lahan umum maupun lahan pekarangan rumah. Selain itu, sanitasi menjadi salah satu indikator kualitas hidup sehat di masyarakat. Dalam kegiatan KRL, pengelolaan sanitasi layak secara menyeluruh diupayakan melalui edukasi meliputi alur pembuangan air limbah rumah tangga, limbah rumah usaha, serta aliran air hujan dan Lubang Resapan Biopori (LRB). Beberapa wilayah Kabupaten Bogor masih banyak yang megalami kekeringan/krisis air, Lubang Resapan Biopori (LRB) sebagai inovasi yang solutif berupaya untuk diterapkan di lokasi Kampung Ramah Lingkungan.

\section{Relasi Gender dan Pembangunan Berkelanjutan}

Puspitawati (2017), mengatakan penanggulangan kesenjangan gender menuju kesetaraan dan keadilan gender merupakan isu global yang merupakan sebuah isu inklusif yang dibutuhkan untuk ditingkatkan di era globalisasi ini. Kerja sama atau relasi gender dapat meningkatkan kecepatan kemajuan pembangunan di segala bidang baik sosial, ekonomi maupun politik. Isu gender dapat dikatakan sebagai cross cutting issue pada setiap lini pembangunan berkelanjutan. Pada penelitiaan Norgaard dan York (2005) menyebutkan bahwa semakin seimbang relasi gender dalam suatu negara makan akan semakin peduli negara tersebut terhadap pembangunan berkelanjutan dan begitu sebaliknya. Pada penelitiaan tersebut produk pembangunan yang dimaksud adalah kebijakan/negara tentang pengelolaan lingkungan hidup. Pada tingkat rumah tangga Puspitawati (2017), menjelaskan bahwa peran dan fungsi keluarga dengan kemitraan gender yang setara dan adil akan membuahkan produksi rumah tangga yang optimal yang akan mendukung produktivitas rumah tangga tersebut. Mengingat rumah tangga adalah unit analisis masyarakat terkecil, maka memerhatikan relasi gender pada tingkat rumah tangga adalah sebuah keniscayaan.

Instruksi Presiden (INPRES) No 9 Tahun 2000 yang mengatur tentang pengarusutamaan gender dalam pembangunan nasional, merupakan bentuk komitmen pemerintah mengawal keadilan dan kesetaraan gender dalam setiap program pembangunan. Hal ini agar tak terulang kembali kesalahan dimasa lalu. Salah satu contoh kebijakan pemerintah yang bias gender pada tahun 80 -an yaitu program swasembada pangan atau revolusi hijau (green revolution) yang secara sosial-ekonomis telah menyingkirkan kaum perempuan dari pekerjaannya sehingga memiskinkan mereka (Probosiwi 2015). Atau yang dialami perempuan nelayan yang tidak dapat membuat kartu nelayan karena yang dianggap nelayan hanyalah yang melaut, mengenyampingkan dukungan perempuan nelayan selain kegiatan melaut.

Menurut Putri (2019), peran perempuan dan keadilan gender sangatlah krusial dalam menyeimbangkan laju pembangunan yang kadang timpang. Gerakan perempuan Chipko Movement di India, Green Belt Movement di Kenya, perlawanan perempuan di Pegunungan Kendeng, gerakan Mama Aleta, seorang tokoh lingkungan dari Mollo, dan gerakan perempuan di tanah Timika hal ini menegaskan bahwa perempuan memiliki peranan sangat penting dalam mengelola lingkungan dan pembangunan. Partisipasi mereka sangat dibutuhkan agar pembangunan dapat berkelanjutan. 


\section{KERANGKA PEMIKIRAN}

Kampung Ramah Lingkungan (KRL) merupakan bentuk nyata pembangunan masyarakat melalui pengelolaan lingkungan yang berbasis pemberdayaan masyarakat. Merujuk pada Inpres No 9 Tahun 2000, setiap program pembangunan harus berperspektif gender dengan konsep gender yang dimaksud adalah kesetaraan dan keadilan gender. Maka menjadi penting untuk menganalisis relasi gender di lingkup kegiatan pembagunan berbasis masyarakat. Untuk mengukur kesetaraan tersebut digunakan teknik analisis gender model Harvard (Puspitawati 2017) yang didalamnya terdapat beberapa variabel yaitu profil aktivitas gender, tingkat akses pada sumber daya, tingkat akses pada manfaat, tingkat kontrol pada sumber daya, dan tingkat kontrol pada manfaat. Ekologi diukur dengan tingkat kelestarian lingkungan dan tingkat pemanfaatan sumber daya alam. Keberlanjutan sosial-budaya diukur dengan tingkat kelestarian budaya dan tingkat interaksi sosial. Sedangkan keberlanjutan ekonomi diukur dengan tingkat kemandirian ekonomi lokal dan taraf hidup.

Pada penelitiaan ini selain melihat kesetaraan gender dalam rumah tangga juga meninjau faktor yang memengaruhinya. Menurut Rokhimah (2014), setidaknya terdapat lima bentuk isu gender di Indonesia yaitu beban kerja ganda, stereotip, kekerasan, subordinasi dan marginalisasi. Menurut Putri dan Lestari (2015), pembagian peran dan pembagian tugas rumah tangga yang adil masih dipengaruhi oleh cara pandang masyarakat mengenai peran gender yang cenderung memosisikan laki-laki hanya berperan pada wilayah publik. Sementara perempuan selalu diposisikan berperan pada wilayah domestik dan ikut dibebankan pekerjaan di wilayah publik (beban ganda). Selain itu, menurut Putri (2010) ketimpangan peran gender juga disebabkan oleh faktor lingkungan seperti budaya, interaksi dengan tokoh masyarakat, kebudayaan masyarakat setempat mengenai penilaian terhadap peran perempuan dan penilaiaan masyarakat setempat terhadap peran laki-laki. Karakteristik rumah tangga menjadi salah satu faktor yang juga memengaruhi relasi gender dalam rumah tangga. Menurut Puspitwati (2012), variabel karakteristik rumah tangga adalah usia suami, usia istri, lama menikah, tingkat pendidikan suami, tingkat pendidikan istri, ukuran keluarga, dan tingkat perkembangan keluarga. Oleh sebab itu, dalam penelitian ini variabel yang digunakan hanya usia suami, usia istri, lama menikah, tingkat pendidikan suami, tingkat pendidikan istri, ukuran keluarga. Sebagai anggota KRL, dalam penelitiaan ini juga akan dilihat hubungan pelaksanaan program KRL yang terdiri dari tingkat partisipasi dan fasilitasi anggota KRL dengan relasi gender dalam rumah tangganya.

Lebih dari itu, penelitiaan ini akan melihat relasi gender yang ada dalam rumah tangga anggota KRL berhubungan dengan keberlanjutan KRL itu sendiri. Keberlanjutan akan diukur dengan beberapa variabel yang sudah lebih digunakan oleh Febriana (2017) dalam penelitiaanya yaitu pada kebelanjutan Namun setelah melalui penyesuaian, pada penelitiaan ini variabel tersebut dimodifikasi menjadi 1) tingkat kebersihan lingkungan; 2) tingkat pengolahan limbah rumah tangga; 3) tingkat interaksi sosial; 4) tingkat partisipasi; dan 5) tingkat fasilitasi. 
Hubungan variabel-varibel tersebut dapat dijelaskan di dalam kerangka pemikiran pada Gambar 1.

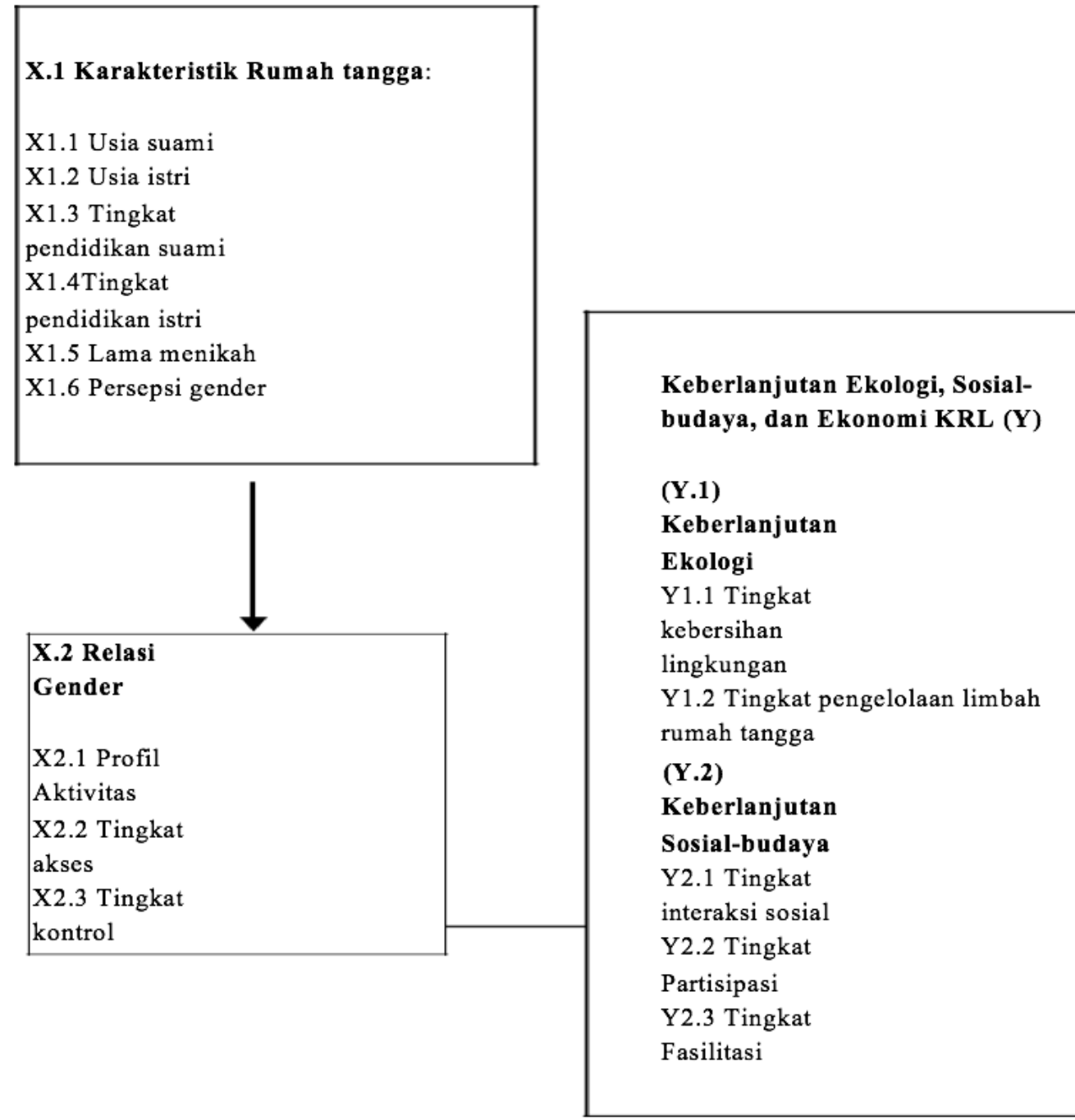

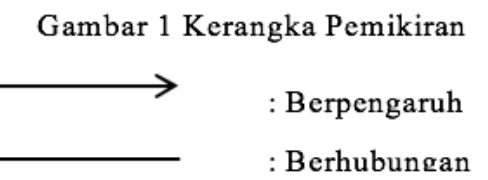

\section{HIPOTESIS PENELITIAN}

Hipotesis pada penelitian ini, diduga karakteristik peserta KRL Pandawa 5 berpengaruh terhadap relasi gender dalam rumah tangga. Selain itu, diduga terdapat hubungan antara relasi gender rumah tangga peserta dan tingkat keberlanjutan KRL Padawa 5.

\section{PENDEKATAN LAPANG}

Penelitian kuantitatif ini menggunakan metode survei dengan instrumen kuesioner untuk memperoleh data kuantitatif. Data kualitatif didapatkan dengan metode wawancara mendalam terhadap informan berdasarkan panduan pertanyaan yang telah dibuat. Sebelum itu, penulis melakukan uji validitas dan reliabilitas terlebih dahulu. Uji validitas dan reabilitas dilakukan lokasi yang sama dengan jumlah responden 10 rumah tangga. Hasil uji validitas menunjukan terdapat beberapa pertanyaan yang tidak 
valid sehingga kemudian penulis mengganti beberapa pertanyaan pada kuesioner serta melakukan perbaikan lainnya. Hasil uji reabilitas pada kuesioner karakteristik rumah tangga menunjukan skor Cronbach's alpha sebesar 0,701. Hasil uji reabilitas pada kuesioner relasi gender menunjukan skor Cronbach's alpha sebesar 0,712. Hasil uji reabilitas pada kuesioner tingkat keberlanjutan ekologi dan sosial-budaya menunjukan skor Cronbach's alpha sebesar 0,805.

Pemilihan lokasi penelitian dilakukan secara purposive (sengaja) berdasarkan hasil penjajakan. Penelitian dilakukan di RW 5 Kelurahan Pabuaran Mekar, Kecamatan Cibinong, Kabupaten Bogor, Provinsi Jawa Barat. Terdapat dua subjek dalam penelitian ini, yaitu responden dan informan. Responden adalah pihak yang memberikan data/informasi mengenai dirinya sendiri. Responden adalah sumber data utama yang akan menjelaskan pengaruh faktor internal dan eksternal yang dimilikinya terhadap relasi gender dalam rumah tangga. Sementara itu, informan adalah pihak yang memberikan informasi tambahan dan keterangan yang penelitian ini perlukan tentang diri sendiri, lingkungan, keadaan pembangunan di RW 5 Kelurahan Pabuaran Mekar. Populasi dalam penelitian ini berjumlah 42 rumah tangga anggota KRL Pandawa 5 yang dinyatakan aktif dalam kegiatan KRL Pandawa 5. Penelitian ini menggunakan teknik simple random sampling untuk menentukan jumlah sampel yang diambil. Pada pengambilan sampel penulis menggunakan rumus Slovin dan didapatkan sampel sebanyak 29,5 responden yang kemudian dibulatkan menjadi 30 responden.

Metode pengambilan sampel acak sederhana dilakukan dengan menggunakan daftar seluruh populasi disertai susunan nomor urut tiap individu dimulai dari angka 1 hingga 42, lalu memilih nomor secara sembarang kemudian nomor tersebut dimasukan kedalam daftar kerangka sampling. Untuk itu sudah mewakili jumlah minimal responden yang dibutuhkan agar data valid. Responden pada rumah tangga sendiri diwakili oleh pasangan suami dan istri. Informan dipilih secara purposive yaitu berdasarkan pertimbangan tertentu. Informan penelitian yang dipilih adalah opinion leader yang terlibat langsung di KRL Pandawa 5 dan pembangunan di Kelurahan Pandawa 5 seperti ketua KRL, Ketua RW dan Ketua RT.

\section{GAMBARAN UMUM KAMPUNG RAMAH LIGKUNGAN PANDAWA 5}

Kampung Ramah Lingkungan (KRL) Pandawa 5 adalah sebuah komunitas penggerak kesadaran menjaga lingkungan yang beranggotakan warga Perumahan Bukit Pabuaran Indah. Perumahan Pabuaran Indah sudah berdiri sejak tahun 1992, terdiri dari 17 RT yang dulunya merupakan RW 17 kelurahan Pabuaran, namun sejak Januari tahun 2017 berubah menjadi RW 05 yang menjadi asal angka 5 pada KRL Pandawa 5. Luas wilayah RW 05 mencapai 5 Ha yang terdiri dari 850 rumah dengan total Kepala Keluarga (KK) 833, total penduduk berjumlah 3045 dengan rincian jumlah warga laki-laki 1503 jiwa dan jumlah warga perempuan 1542 jiwa. KRL Pandawa 5 memiliki visi yaitu mewujudkan lingkungan RW 05 Kelurahan Pabuaran Mekar menjadi lingkungan yang bersih, indah sehat, tertib dan aman. Serta warga memiliki jargon untuk saling memotivasi yaitu "bersih, sehat, dimulai dari saya". Istilah KRL bukan murni inisiatif warga sekitar, melainkan bentuk implementasi tingkat RW dari kebijakan pemeritah Kabupaten Bogor. Sebelum menggunakan istilah KRL, warga Pabuaran Indah sudah lebih dulu memiliki program rutinan yang berorientasi pada kebersihan lingkungan seperti lomba kebersihan lingkungan antar RT dan kegiatan sosial lainnya seperti Posbindu dan Posyandu. Sejak adanya sosialisasi oleh Dinas Lingkungan Hidup (DLH) kabupaten Bogor mengenai KRL menjadi motivasi tersendiri bagi penggurus RW dan anggotanya untuk memformalkan gerakan ini. Untuk bertransformasi menjadi KRL maka RW 05 membentuk beberapa pokja yaitu, pokja pendidikan, pokja pemberdayaan masyarakat, pokja penghijauan, pokja pengolahan sampah organik, pokja pemilahan sampah non organik (bank sampah dan bank jelantah), pokja sanitasi dan konservasi, dan pokja penataan lingkungan. Hingga kini sudah sebanyak 52 orang yang menjadi pengurus KRL Pandawa 5 dengan rincian 52 orang tersebut adalah perwakilan warga tiap RT nya. "KRL itu kan awal terbentuknya kan sangat sederhana ya Mba ya. Karena kita belum, semuanya belum begitu paham, bahkan dari instansi juga belum banyak yang menjelaskan dan memberikan informasi...”(Ibu AG, Ketua KRL, 51 tahun) 
Hingga saat ini terdapat lima kegiatan utama KRL Pandawa 5 yaitu sedekah sampah (bank sampah) dan sedekah jelantah setiap dua kali dalam sebulan. mengolah sampah menjadi kerajinan, menanam tanaman hidroponik, menanam tanaman toga, dan pembuatan lubang serapan/biopori. Kegiatan sedekah sampah dan sedekah jelantah di KRL Pandawa 5 bermuara dipengempul langganan RW sehingga terdapat nilai

ekonomis didalamnya. Namun, keuntungan tersebut tidak digunakan untuk kebutuhan pribadi melainkan untuk ditabung menjadi kas RT masing-masing. "Kegiatan bank sampah bikin saya sempat ditolak warga tuh mba, karena dibilang mengambil haknya pemulung, tapi setelah saya jelaskan dan beri pengertian, alhamdulillah sekarang sudah pada ikut." (Ibu AG, Ketua KRL, 51 tahun)

Sejak bertransformasi menjadi Kampung Ramah Lingkungan, KRL Pandawa 5 sudah banyak memperoleh penghargaan dan memenangkan perlombaan diantaranya yang terbaru memeroleh penghargaan sebagai Ecovillage kategori lanjutan 2019 dalam kegiatan Ecovillage Award 2019, serta memeroleh penghargaan sebagai KRL jawara dalam program Bogor Kabupatenku Green and Clean (BKGC) tahun 2019 dan penghargaan sebagai KRL Best of The Best dalam program Bogor Kabupatenku Green and Clean (BKGC) tahun 2019. Selain itu KRL Pandawa 5 juga beberapa kali kedatangan komunitas serupa atau instansi pemerintah kota/kabupaten lain baik dari pulau jawa maupun luar pulau jawa yang hendak

belajar mengebaik KRL dan pengelolaannya. Adanya KRL Pandawa 5 di Perumahan Pabuaran Indah terbukti meningkatkan kesadaran warganya untuk menjaga kebersihan lingkungan dan lebih dari itu ikatan sosial antar warga pun terjalin semakin kuat serta kompak.

\section{KARAKTERISTIK RESPONDEN}

Pada responden rumah tangga kampung ramah lingkungan pandawa 5 mayoritas usia suami adalah rentang 49-55 tahun dan usia istri pada rentang 49-54 tahun. Tingkat pendidikan istri paling banyak berada pada tingkatan sedang yaitu tamat/tidak tamat SMA/sederajat. Sementara itu, pada tingkatan pendidikan suami memiliki persentase yang imbang antara tingkatan sedang dan tinggi. Mayoritas rumah tangga pada kampung ramah lingkungan sudah menikah selama 24-8 tahun.

\section{HASIL DAN PEMBAHASAN}

\section{Peran Gender}

Pada penelitian ini pembagian peran gender mengacu pada tiga jenis pembagian peran gender menurut Moser (1993). Seperti yang sudah penulis sampaikan pada tinjauan pustaka. Moser (1993) membagi peran tersebut menjadi tiga kategori yang pertama, peranan produktif, yaitu peranan yang dikerjakan perempuan dan laki-laki untuk memperoleh bayaran tunai, termasuk produksi pasar dengan suatu nilai tukar dan produksi rumah tangga/subsisten dengan nilai guna. Kedua, peranan reproduktif merupakan peranan yang berhubungan dengan tanggung jawab pengasuhan anak dan tugas-tugas domestik untuk menjamin pemeliharaan dan reproduksi tenaga kerja yang menyangkut kelangsungan tenaga. Terakhir, peranan sosial dan politik, terdiri atas 2 (dua) peranan pengelolaan masyarakat (kegiatan sosial), mencakup semua aktivitas dalam komunitas sebagai kepanjangan peran reproduktif, bersifat sukarela (tanpa upah).

Mayoritas pembagian peran produktif pada rumah tangga responden, yaitu sebanyak 47 persen memiliki pembagian peran produktif yang kurang setara, 43 persen cukup setara dan 10 persen yang setara. Sejalan dengan yang dikatakan Hikmah A dan Pranowo (2012) bahwa kaum laki-laki mempunyai anggapan bahwa laki-laki adalah pihak yang bertanggung jawab dalam mencari nafkah utama untuk kebutuhan ekonomi rumah tangga atau laki-laki sebagai pekerja produktif yang dominan. Sebanyak 50 persen pecarian nafkah utama rumah tangga dilakukan oleh laki-laki saja. Pekerjaan mencari nafkah yang dimaksud pada kasus rumah tangga KRL pandawa 5 antara lain sebagai guru, konsultan bisnis, konsultan kehutanan dan perkebunan pegawai BUMN, polisi, pedagang dan karyawan swasta. Jika di lihat dari ragam jenis pekerjaan utamanya maka dapat mengambarkan 
padatnya rutinitas pekerjaan kantoran yang dimiliki oleh para pencari nafkah utama rumah tangga responden. Terdapat satu responden yang menjawab pilihan "perempuan saja" dalam rincian pembagian peran produktif.

Namun, hal itu disebabkan karena sang suami sudah pensiun yang artinya sebelum itu sang suami juga menjalankan peran produktif. Oleh sebab itu, dapat disimpulkan bahwa pembagian peran produktif rumah tangga responden KRL Pandawa 5 didominasi oleh laki-laki. Namun, selain itu pada rincian pembagian peran produktif: memiliki pekerjaan sampingan, mayoritas respoden memilih pilihan "bersama". Hal ini dilakukan paling banyak untuk alasan menunjang perekonomian rumah tangga dengan istri yang melakukan peran produktif yaitu usaha sampingan. Pada peran reproduktif mayoritas responden menjawab kegiatan reproduktif dilakukan bersama-sama. Hampir tidak ada pekerjaan yang dilakukan laki-laki saja atau dominan laki-laki. Meskipun dilakukan bersama, tetap saja, pada peran reproduktif dilakukan dominan oleh perempuan atau hanya perempuan saja. Keadaan tersebut sejalan dengan yang dikatakan oleh Elizabeth (2008) bahwa pada pada dasarnya perempuan memang memiliki peran ganda. Rincian pekerjaan yang dilakukan perempuan seperti memasak, mencuci pakaian dan mencuci piring. Zaman yang semakin modern bukan jaminan stereotipe bahwa pekerjaan rumah tangga adalah tanggung jawab perempuan hilang. Banyaknya jasa asisten rumah tangga tak menjadi solusi. Mayoritas rumah tangga responden penelitian ini berpendapat, baik rumah tangga dengan istri yang bekerja atau tidak, istri harus menyempatkan untuk membereskan rumah terlebih dahulu sebelum beraktivitas di luar rumah. Suami bukan sama sekali tidak membantu, karena terdapat pula rumah tangga responden yang pekerjaan mencuci pakaian menjadi tanggung jawab bersama bahkan laki-laki saja. Hal ini ditunjang dengan teknologi mesin cuci yang menjadikan pekerjaan lebih mudah bagi laki-laki. Relasi gender dalam rumah tangga Kampung Ramah Lingkungan (KRL) Pandawa 5 termasuk pada golongan yang cukup setara. Pembagian peran produktif masih tergolong cukup setara dikarenakan masih didominasi laki-laki. Pembagian peran reproduktif dan sosial sudah cukup setara walau masih ada beberapa kegiatan yang masih di dominasi oleh salah satu gender, seperti pada rincian pembagian peran reproduktif. Tingkat akses dan kontrol dalam rumah tangga KRL Pandawa 5 juga tergolong pada kategori cukup setara.

\section{Pengaruh Karakteristik Rumah Tangga Terhadap Relasi Gender Dalam Rumah Tangga}

Karakteristik rumah tangga yang berpengaruh terhadap relasi gender dalam rumah tangga adalah tingkat pendidikan suami dan tingkat pendidikan istri. Nilai signifikansi yang dihasilkan dari pengujian antara tingkat pendidikan suami dengan relasi gender adalah 0,028 dan nilai signifikansi tingkat pendidikan istri dengan relasi gender adalah 0,044. Selain itu Hasil pengujian menunjukan bahwa tidak ada pengaruh usia suami, usia istri, lama menikah dan persepsi gender dalam rumah tangga terhadap relasi gender karena semua nilai signifikansi yang diperoleh $p>0,05$. Namun pada variabel tingkat tingkat pendidikan suami $t_{\text {hitung }}$ yang diperoleh bernilai negatif yang berarti semakin tinggi pendidikan suami semakin kurang setara relasi gender dalam rumah tangga tersebut. Temuan ini bersifat khusus yang berarti tidak dapat diambil kesimpulan secara umum bahwa semakin rendah tingkat pendidikan suami maka akan semakin setara relasi gender dalam setiap rumah tangga.

Berdasarkan uji statistik yang dilakukan pada indikator-indikator karakteristik rumah tangga seperti usia, tingkat pendidikan, persepsi gender dan lama menikah sebuah rumah tangga hanya tingkat pendidikan suami dan istri yang memiliki pengaruh yang signifikan terhadap relasi gender dalam rumah tangga. Tingkat pendidikan istri arah pengaruh yang positif sedangkan tingkat pendidikan suami memiliki arah pengaruh yang negatif. Pada indikator karakteristik rumah tangga lainnya pengaruh yang diberikan tidaklah signifikan menjamin semakin tinggi tingkatannya semakin setara relasi gender dalam rumah tangga. Namun hal ini tetap membuktikan bahwa hipotesis penelitian ini mengenai ada indikator karakteristik rumah tangga yang mempengaruhi relasi gender dalam rumah tangga diterima. 


\section{Hubungan Relasi Gender dan Keberlanjutan KRL Pandawa 5}

Berdasarkan hasil uji statistik korelasi didapatkan adanya hubungan yang signifikan antara tingkat relasi gender dengan tingkat keberlanjutan sosial-budaya KRL Pandawa 5. Nilai koefisien korelasi yang diperoleh yaitu 0.046 , hasil ini $p<0.05$ yang berarti $\mathrm{H}_{0}$ diterima. Arah hubungannya didapatkan negatif atau dapat diartikan sebagai hubungan yang berkebalikan. Arah hubungan yang diperoleh negatif ini tergambar dalam tabulasi silang diatas (Tabel 21). Semakin kurang setara tingkatan relasi gender dalam suatu rumah tangga maka semakin tinggi tingkatan keberlanjutan sosial-budaya.

Berdasarkan data temuan lapang, rumah tangga yang tingkatan relasi gendernya kurang setara adalah rumah tangga yang pada rincian pembagian peran produktifnya masih didominasi oleh salah satu gender. Hubungannya dengan keberlanjutan sosial budaya adalah rumah tangga yang peran produktifnya masih didominasi oleh laki-laki tersebut menyebabkan perempuan yang mayoritas bekerja sebagai ibu rumah tangga yang banyak melakukan interaksi sosial antar angggota KRL, partisipasi pada kegiatan KRL dan menerima fasilitas dari Kegiatan KRL.

Berbeda dengan rumah tangga yang ada pada tingkatan cukup setara sampai setara, dimana peran produktif mayoritas dilakukan kedua gender, suami dan istri sama-sama bekerja, maka partisipasinya pada kegiatan sosial-budaya KRL pandawa 5 sangat rendah. Sebagai contoh responden Ibu WN (40 tahun) yang bekerja sebagai wiraswata mengatakan bahwa waktunya sangat sempit untuk diluangkan terhadap agenda-agenda KRL. Jika ada acara besar maka beliau akan menyempatkan. Begitupun dengan Ibu SL (50 tahun) seorang karyawan swasta yang memiliki jadwal cukup padat tiap harinya. Hal ini berkaitan dengan teori struktural-fungsional yang disampaikan oleh Klein dan White (1996) dalam Puspitawati (2017) bahwa konsep keseimbangan mengarah pada konsep kemampuan menjaga stabilitas agar keberlangsungan suatu sistem tetap terjaga dengan baik. "Jarang mba saya ikut, apalagi kalo yang buat kerajinan, waktunya itu ga sempet, saya kan dikantor dari pagi sampai sore ga di kompleks, bapak juga sama. Paling kalo ada acara gede kayak lomba-lomba gitu baru saya bisa atau pas hari libur" (Ibu SL, 50 tahun)

Tingkat Relasi gender dalam rumah tangga Kampung Ramah Lingkungan (KRL) Pandawa 5 memiliki hubungan yang signifikan terhadap keberlanjutan sosial-budaya KRL. Arah hubungannya negative atau berkebalikan. Sementara tingkat relasi gender tidak memliki hubungan dengan tingkat keberlanjutan ekologi KRL. Keberlanjutan Ekologi bergantung akan kepekaan dan kepedulian masing-masing individu warga RW 5 pada lingkungan

\section{KESIMPULAN}

Berdasarkan hasil penelitian, terdapat beberapa kesimpulan yaitu relasi gender dalam rumah tangga anggota KRL Pandawa 5 termasuk ke dalam ketegori yang cukup setara, karakteristik rumah tangga yang memiliki pengaruh signifikan terhadap tingkat relasi gender dalam rumah tangga adalah tingkat pendidikan suami dan tingkat pendidikan istri. Arah pengaruh tingkat pendidikan suami bersifat negatif, hal ini menunjukkan semakin tinggi tingkat pendidikan suami maka semakin kurang setara pembagian peran dalam rumah tangga tersebut. Namin, hal ini merupakan temuan kasus khusus di KRL Pandawa 5, yang berbeda kemungkinan besar akan berbeda hasilnya pada lokasi lain. Sementara itu pengaruh tungkat pendidikan istri bersifat positf. Hal ini berarti semakin tinggi pendidikan istri maka akan semakin setara relasi gender dalam rumah tangga tersebut. Selain itu, terdapat hubungan antara tingkat relasi gender dalam rumah tangga dengan keberlanjutan sosial dan budaya KRL Pandawa 5. Hubungan yang bersifat negatif yang berarti bahwa semakin setara pembagian relasi gender dalam rumah tangga, semakin rendah keberlanjutan 
sosial-budaya pada KRL Pandawa 5. Hal ini juga dinyatakan sebagai kasus yang hanya berlaku di KRL Pandawa 5 dengan keadaan sosiologis KRL desa lain maka hasilnya akan mungkin berbeda. Pada hubungan relasi gender dengan keberlanjutan ekologi tidak diperoleh hubungan yang signfikan. Hal ini dikarenakan keberlanjutan ekologi diyakini membutuhkan kesadaran dan kepekaan masingmasing indvidu dalam KRL tersebut.

\section{SARAN}

Merujuk pada penelitian yang telah dilakukan, berikut adalah beberapa saran yang diberikan oleh peneliti, antara lain: (1) Bagi pemerintah Kecamatan Cibinong serta Dinas Lingkungan Kabupaten Bogor, perlu serius dalam pendampingan kegiatan KRL ini. Pendampingan maksimal sangat dibutuhkan. Jeda waktu tiap pendampingan disarankan bukan per 6 bulan sekali melainkan setiap sebulan sekali agar pendampingan maksimal; (2) Bagi akademisi, perlu dilakukan kajian lebih lanjut mengenai faktor-faktor yang menyebabkan hubungan tingkat pendidikan suami dan relasi gender bersifat negatif di KRL Pandawa 5 dan melakukan uji beda untuk daerah dengan karakteristik yang tidak jauh berbeda. Serta, kajian lebih lanjut mengenai faktor yang mempengaruhi hubungan relasi gender.

\section{DAFTAR PUSTAKA}

Asdak C. 2012. Kajian Lingkungan Hidup Strategis: Jalan Menuju Pembangunan. Gadjah Mada University Press. Yogyakarta Asmarani NNO. 2018. Ekofeminisme dalam antroposen: relevankah? Kritik gagasan ekofeminisme. [internet]. Jurnal Multidisipliner Mahasiswa Indonesia. 1(1): 128-143. [diunduh pada 22 januari 2020]. Tersedia pada https://jurnal.ugm.ac.id/balair ung/article/view/34987/20817

Elizabeth R. 2008. Peran Ganda Wanita Tani dalam Mencapai Ketahanan Pangan Rumah Tangga. Iptek Tanaman Pangan. 3(01). [diunduh pada 4 februari 2020]. Tersedia pada http://pangan.litbang.pertanian.go.id/files/05-Roosganda.pdf

Fauzi A, Oxtavianus A. 2014. Pengukuran Pembangunan Berkelanjutan di Indonesia. [internet]. Jurnal Mimbar. 30 (1): 42-52. [diunduh pada 4 februari 2020]. Tersedia pada https://ejournal.unisba.ac.id/index.php/mimbar/article/download/445/759

Febriana H. 2017. Hubungan Partisipasi masyarakat dengan keberlanjutan ekologi, sosial-budaya, dan ekonomi dalam ekowisata desa adat. [skripsi]. [internet]. [diunduh pada 3 februari 2020]. Tersedia pada https://repository.ipb.ac.id/bitstream/handle/123456789/88017/ I17hfe.pdf? sequence $=1 \&$ is Allowed $=\mathrm{y}$

Gelgel NMRA. 2016. Perempuan gianyar dan belenggu ranah publik dan privat [internet]. Jurnal Kajian Bali. 6(1): 173-210. [diunduh 27 Desember 2018]. Tersedia pada: https://ojs.unud.ac.id/index.php/kaj ianbali/article/view/19905

Hayati, Siti Amanah et al. 2015. Kemampuan perempuan tani dalam mendukung ketahanan pangan rumah tangga [internet]. Jurnal Sosiohumaniora. 18 (03) 229 -235 [diunduh 29 april 2019]. Tersedia pada: https://doi.o rg/10.24198/sosiohuman iorav17i3.8340

Handajani H, Relawati R, Handayanto E. 2015. Peran gender dalam keluarga nelayan tradisional dan implikasinya pada model pemberdayaan perempuan di Kawasan Pesisir Malang Selatan [Internet]. Jurnal Perempuan dan Anak. 1(1): 1-21. [diunduh 27 Desember 2018]. Tersedia pada: http://ejournal.umm.ac.id/index.php/JPA /article/view/2745

Herawati N. 2000. Faktor-Faktor Yang Mempengaruhi Persepsi Remaja SMU Tentang Peran Gender Tradisional [skripsi]. [internet]. [diunduh pada 20 Februari 2020]. Tersedia pada https://repository.ipb.ac.id/bitstream/handle/123456789/21446/A00nhe2.pdf?sequence=2\&is Allowed=y [INPRES]

Instruksi Presiden Republik Indonesia Nomor 9 Tahun 2000 tentang pengarusutamaan gender dalam pembangunan nasional

Keraf AS. 2000. Etika Lingkungan Hidup.Jakara. Kompas 
Rokhimah E. 2014. Diskriminasi gender terhadap perempuan dalam sector pekerjaan. [internet]. Jurnal Yinyang. 4(1): 158-180. [diunduh pada 20 februari 2020]. Tersedia pada http://ejournal.iainpurwokerto.ac.id/index.php/yinyang/article/download/ $226 / 196$

Mugniesyah. 2007. Gender, Lingkungan dan Pembangunan. [Internet]. [diunduh pada: 28 Januari 2020]. Tersedia pada http://repository.ipb.ac.id/handle/123456789/76150

Moser C.1993. Gender Planning and Development: Theory, Practice and Training. [internet].

Norgaard K, York R. 2005. Gender Equality and State Environmentalism. Gender \& Society. 19(4): 506-522. Sociologist for women in society

Novriani M, Fatchiya A. 2011. Persepsi perempuan tentang perannya dalam rumah tangga pembudidaya kerang hijau [ internet]. Jurnal Sodality. 5(3): 235-246. [diunduh januari 2019]. Tersedia pada http://ejournal skpm.ipb.ac.id/index. $\mathrm{php} /$ sodality/article/view/433

[PERDA] Peraturan Daerah Kabupaten Bogor Nomor 6 Tahun 2015 [PERMEN] Peraturan menteri Negara Lingkungan Hidup Republik Indonesia Nomor 19 Tahun 2012

Probosiwi R. 2015. Perempuan dan Perannya dalam pembangunan kesejahteraan sosial. [Internet]. Jurnal Kajian Ilmu Administrasi Negara. 3(1): 41-56. [diunduh 20 januari 2020]. Tersedia pada https://journal.uny.ac.id/index.php/natapraja/article/download/11957/8553

Prasodjo NW et al. 2003. Modul Mata Kuliah Gender dan Pembangunan, Departemen Komunikasi dan Pengembangan Masyarakat. Bogor [ID]: Institut Pertanian Bogor. Tidak dipublikasikan. Profil Kelurahan Pabuaran Mekar 2019

Puspitawati H. 2012. Persepsi peran gender terhadap pekerjaan domestik dan publik pada mahasiswa ipb [Internet]. Jurnal Studi Gender dan Anak. 5(1): 17-34. [diunduh 27 Desember 2018]. Tersedia pada:http://ejournal.iainpurwokerto.ac.id/index.php/yinyang/article/view/244/214

Puspitawati, H. 2017. Gender dan Keluarga: Konsep dan Realita di Indonesia. IPB Press. Bogor.

Puspitasari N, Puspitawati H, Herawati T. 2013. Peran gender, kontribusi ekonomi perempuan, dan kesejahteraan keluarga petani hortikultura [Internet]. Jurnal Ilmu Keluarga dan Konsumen. 6(1): 10-19. [diunduh 27 Desember 2018]. Tersedia pada: http://dx.doi.org/10.24156/jikk.201 3.6.1.10

Putri RS. 2010. Relasi Gender Pada Rumah Tangga Petani Sayuran Dataran Rendah. [Skripsi]. [Internet]. [Diunduh pada 22 januari 2020]. Tersedia pada https://repository.ipb.ac.id/bitstream/handle/123456789/27310/I10srp.pdf?sequance=11\&isAll owed $=\mathrm{y}$

Putri DPK, Lestari S. 2015. Pembagian peran dalam rumah tangga pada pasangan suamu istri jawa [Internet]. Jurnal Penelitian Humaniora. 16 (1): 72-85. [Diunduh 27 Desember 2018]. Tersedia pada: https://doi.org/10.23917/humaniora.v16il.1523

[PP] Peraturan Persiden Republik Indonesia Nomor 59 Tahun 2017 tentang pelaksanaan pencapaian tujuan pembangunan berkelanjutan.

Rahma AL. 2019. Faktor-Faktor Yang Mempengaruhi Tingkat Keaktifan Perempuan Untuk Menjaga Lingkungan Dalam Perspektif Ekofeminisme. [Skripsi]. [internet]. [diunduh pada 10 januari 2020]. Tersedia pada https://repository.ipb.ac.id/bitstream/handle/123456789/97428/I19anr.pdf?sequence=1\&isAllo wed $=\mathrm{y}$

Ulfah N. 2017. Analisi Gender Program Kampung Ramah Lingkungan. [skripsi]. [internet]. [diunduh $\begin{array}{lllll}\text { pada } & 3 & \text { februari } & \text { 2020]. } & \text { Tersedia }\end{array}$ https://repository.ipbac.id/bitstream/handle/123456789/88463/I17nul.pdf?sequence=1\&isAllo wed $=\mathrm{y}$

[UNESCO] United Nations Educational, Scientific and Cultural Organization. 2000. A summary review of UNESCO's accomplishments since the Fourth World Conference on Women (Beijing 1995) [Internet]. [Diunduh pada 20 Februari 2020]. Tersedi pada https://unesdoc.unesco.org/ark:/48223/pf0000121145 
Widayani NMD, Hartati S. 2014. Kesetaraan dan keadilan gender dalam pandangan perempuan bali: studi fenomenologis terhadap penulis perempuan bali [Internet]. Jurnal Psikologi Universitas Diponegoro. 13(2):149-162. [diunduh 27 Desember 2018]. Tersedia pada: https://doi.org/10.14710/jpu.13.2.149-162 